Секция 9. Углеродные и графеноподобные наноматериалы, дихалькогениды переходных металлов, перовскиты, органические полупроводники, молекулярные системы

\title{
Перенос энергии в гибридных светоизлучающих структурах между нанокристаллами перовскитов и полимерной матрицей при оптическом и электрическом возбуждении
}

\author{
Алешин А.Н., Чикалова-Лузина О.П., Щербаков И.П., Овезов М.К. \\ ФТИ им. А.Ф. Иоффе РАН, 194021, С.-Петербург, Политехническая ул., 26
}

DOI 10.34077/Semicond2019-367

В последнее время нанокристаллы (НК) перовскитов вызывают большой интерес из-за их уникальных оптических свойств, таких как узкий спектр и перестраиваемая длина волны излучения, высокая квантовая эффективность фотолюминесценции (ФЛ) и др., что делает их перспективным классом материалов для солнечных элементов, светодиодов и светоизлучающих полевых транзисторов (СИ-ПТ) [1]. Введение неорганических перовскитных НК в матрицу светоизлучающих полупроводниковых полимеров улучшает технологичность и стабильность таких гибридных пленок и приборов. В данной работе нами на основе теории Фёрстера рассмотрен перенос энергии безызлучательного возбуждения от перовскитных $\mathrm{HK} \mathrm{CsPbBr}_{3}$ к светоизлучающей матрице полупроводникового полимера MEH-PPV, а также были экспериментально исследованы оптические и электрические свойства гибридных пленок MEH-PPV:CsPbr $3(\mathrm{HK})$. Была исследована зависимость интенсивности ФЛ матрицы MEH-PPV как функция концентрации $\mathrm{HK} \mathrm{CsPbBr}_{3}$ при 300 К. Как теоретически, так и экспериментально было обнаружено снижение интенсивности ФЛ с увеличением концентрации $\mathrm{HK} \mathrm{CsPBr}_{3}$, при этом затухание ФЛ, измеренное экспериментально, оказалось более сильным по сравнению с теоретическим [2]. Были разработаны СИ-ПТ с активными слоями на основе MEH-PPV:CsPbBr $3(\mathrm{HK})$ и исследованы их электрические и оптические свойства. Обнаружено, что СИ-ПТ на основе пленок MEH-PPV:CsPbBr $(\mathrm{HK})$ демонстрируют при 290-100 К вольт-амперные характеристики характерные для дырочного транспорта, а температурная зависимость подвижности $\mu(\mathrm{T})$ свидетельствует о прыжковом механизме проводимости. Установлено, что зависимости интенсивностей ФЛ и электролюминесценции (ЭЛ) композитных пленок MEH-PPV:CsPbBr $3(\mathrm{HK})$ и СИ-ПТ на их основе от величин оптической и электрической мощности возбуждения являются сублинейными и суперлинейными соответственно. При этом интенсивность ЭЛ при $300 \mathrm{~K}$ МЕНPPV:CsPbBr $(\mathrm{HK})$ СИ-ПТ в 100 раз выше, чем у ранее исследованных СИ-ПТ на основе PFO:CsPbI ${ }_{3}(\mathrm{HK})$ и $\mathrm{PFO}: \mathrm{CsPBr}_{3}(\mathrm{HK})[3,4]$. Рассмотрены механизмы излучательной рекомбинации и переноса энергии в таких структурах при оптическом и электрическом возбуждении. Обсуждаются причины количественных различий между экспериментальными и теоретическими результатами для зависимостей интенсивности ФЛ от концентрации НК в пленках MEH-PPV:CsPbBr $3\left(\mathrm{HK}_{2}\right.$. Более высокая интенсивность ЭЛ наблюдаемая в СИ-ПТ на основе пленок MEH-PPV:CsPbBr $3(\mathrm{HK})$ по сравнению с СИ-ПТ на основе $\mathrm{PFO} \mathrm{CsPbI}_{3}(\mathrm{HK}), \quad \mathrm{PFO}: \mathrm{CsPbBr}_{3}(\mathrm{HK})$ может быть связана с эффективным переносом энергии в MEH-PPV:CsPbBr $3(\mathrm{HK})$ гибридных светоизлучающих структурах между НК перовскитов и полимерной матрицей при оптическом [2] и электрическом возбуждении.

[1] H.-C. Wang et al., Small 14, 1702433 (2018).

[2] O.P. Chikalova-Luzina, A.N. Aleshin et al., Synth. Metals 246, 230 (2018).

[3] A.N. Aleshin et al., Organic Electronics 50, 213 (2017).

[4] A.N. Aleshin et al., Phys. Sol. St., 61, 256 (2019). 